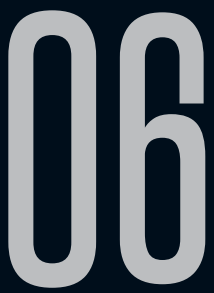

\title{
CRAKENSTEIN'S BRAVE NEW PANDEMIC WORLD: THE PLACE OF ART, SCIENCE, AND STORYTELLING ${ }^{1}$
}

Renata Pires de Souza

Recebido em 02 nov 2020. Renata Pires de Souza é mestre.

Aprovado em 14 dez 2020.

http://lattes.cnpq.br/5220367251756139

https://orcid.org/0000-0003-1908-1325

repiress@yahoo.com.br

Abstract: The present article aims at examining the place of art, science, and storytelling in Margaret Atwood's Oryx and Crake (2003), comparing the novel to Mary Shelley's Frankenstein (1818) and Aldous Huxley's Brave New World (1932), mainly in what concerns some characters who are on the margins of society. In this context, scientific knowledge set against the humanistic one is the generating principle of social inequalities, and people concerned with arts are relegated to an inferior place. In the three novels, those who value words amid the techno-scientific developments of society are condemned to live alone for not fitting in. However, Oryx and Crake presents a possible rereading of Shelley's and Huxley's works, leading the central character to a less tragic closure, even though still in a devastated landscape. Ironically, in the aftermath of a pandemic, when the rules of science do no longer apply, it is a "words person" who

1 This article stems from a larger research project, which can be found in my Master thesis entitled Armageddon has only begun: utopian imagination in Margaret Atwood's Oryx and Crake (2014). In the thesis, there is a more comprehensive study on science, speculative and apocalyptic fiction, as well as the concepts of utopia and dystopia. 
survives, embracing his existence through the act of storytelling. Atwood's novel, therefore, celebrates and updates the classics in some way, transposing them to a brand-new universe, where - through her apocalyptic visions - it is also possible to draw a parallel with the new coronavirus pandemic we have faced in the real scenario.

Keywords: Dystopian fiction. Apocalyptic fiction. Art. Science. Storytelling.

Resumo: O presente artigo tem como objetivo examinar o lugar da arte, da ciência e da narrativa em Oryx e Crake (2003), de Margaret Atwood, comparando o romance a Frankenstein (1818), de Mary Shelley, e Admirável Mundo Novo (1932), de Aldous Huxley, sobretudo no que diz respeito a personagens que se encontram à margem. Nesse contexto, o conhecimento científico em oposição ao humanístico é o princípio gerador das desigualdades sociais, e as pessoas preocupadas com as artes são relegadas a um lugar inferior. Nos três romances, quem valoriza a palavra em meio aos desenvolvimentos tecno-científicos da sociedade é condenado a viver sozinho por não se enquadrar. Contudo, Oryx $e$ Crake apresenta uma possível releitura das obras de Shelley e Huxley, levando o personagem central a um desfecho menos trágico, embora ainda em uma paisagem devastada. Ironicamente, na sequência de uma pandemia, quando as regras da ciência não mais se aplicam, é uma "pessoa de palavras" que sobrevive, abraçando sua existência através do ato de contar histórias. O romance de Atwood, portanto, celebra e atualiza de alguma forma os clássicos, deslocandoos para um novo universo, onde - por meio de suas visões apocalípticas - também é possível fazer um paralelo com a pandemia do novo coronavírus que enfrentamos no cenário real.

Palavras-chave: Ficção distópica. Ficção apocalíptica. Arte. Ciência. Narrativa. 
I felt convinced that however it might have been in former times, in the present stage of the world, no man's faculties could be developed, no man's moral principle be enlarged and liberal, without an extensive acquaintance with books. Mary Shelley, The Last Man

There must be something in books, things we can't imagine, to make a woman stay in a burning house; there must be something there. You don't stay for nothing. Ray Bradbury, Fahrenheit 451

\section{INTRODUCTION}

Since the beginning of the universe, one may contemplate science and art in a sort of contention. Sometimes subtle, sometimes brutal, the dispute is there. Why is that so? According to George Slusser and George Guffey, "though highly respected, science is, of course, not the only human activity widely admired and supported. Art is another such activity" (1982, p.176). Although this statement is correct, the thing is the role of art has often been neglected throughout the history of literature, especially in science fiction and dystopian narratives, in which art is less important whereas science reigns triumphant. At times celebrated, others strongly criticized, it is unquestionable that scientific developments have an important role in literature, either by means of good use of science or, perhaps to a greater extent, misuse of science. Thus, we alternate between major inventions and major disasters caused by the mad scientist who sets himself above ordinary people. 
Slusser and Guffey also state that "as a hero in literature, the scientist or pseudoscientist is essentially a creation of the Renaissance. In Christopher Marlowe's seminal work Doctor Faustus (1604), we watch sin give way to the secular hubris of scientific curiosity" (1982, p. 186). In this context, "the scientist can play various roles: he can conform to or rebel against the scientific 'establishment' itself" (SLUSSER; GUFFEY, 1982, p. 192). Besides, in science fiction, there seems to be a conflict of mind and matter that has ended up in the mad scientist tale, as it happens in Mary Shelley's Frankenstein (1818) and H.G. Wells's The Island of Dr. Moreau (1896) - in which Dr. Moreau "claims to have struggled, in the name of higher human consciousness, against some brutish constant in organic nature" (SLUSSER; GUFFEY, 1982, p. 197). The list of troubled men acting in the name of scientific curiosity is endless. In addition,

from Frankenstein onwards scientific discovery is as much a threat as it is a promise. In H. G. Wells's The Island of Dr. Moreau (1896) the biologist's attempt to accelerate evolution according to Darwinian principles only causes rapid regression to bestial states and unleashes a reversion to savagery and a host of horrible hybrid creatures. (BOTTING, 2002, p. 279)

One may recognize that science fiction derives its conventions from the gothic novel, though its origins are still a bit vague. Even if there are scientific traits in literary works from the nineteenth century, such as Mary Shelley's and Edgar Allan Poe's, there are also scientific elements in works from the eighteenth century, such as Jonathan Swift's Gulliver's Travels (1726), which makes it 
almost impossible to establish a definite origin for the genre. In general terms, "science fiction is that branch of literature which is concerned with the impact of scientific advance upon human beings" (ASIMOV apud SLUSSER; GUFFEY, 1982, p. 194). Some characteristics are the presence of robots, alternative timelines, time travel, outer space and aliens, technology and scientific principles. Moreover, another important feature often associated with science fiction is the dystopian mood, bringing a situation in which an organized society has collapsed.

Dystopian fiction: (from the Greek dys "ill, bad, diseased" and topos "place"; sometimes referred to as "negative" or "pessimistic" utopia) the presentation of a possible world that is the nightmarish opposite of perfection; has its origins in the satirical use of utopian fiction in such works as Swift's Gulliver's Travels and Samuel Butler's Erewhon but to a large extent is a product of twentieth-century pessimism (e.g., Zamyatin's We, Huxley's Brave New World, and Orwell's 1984). (BARRICELLI; GIBALDI, 1982, p. 309)

For sure, science fiction is not necessarily dystopic, and dystopia is not necessarily scientific, either. Nevertheless, the literary works addressed for the purposes of this article seem to have a strong connection with one or the other, or even with both. Published in 1818, Mary Shelley's Frankenstein gave birth to the modern science fiction novel, so it is a starting point in many senses. Inspired by the Romantic Movement and the gothic horror theme, the book draws an idea dreamed up by many, the power of creation by human hands. The Doppelgänger is present in multiple layers and different characters in the novel, though 
what really calls the reader's attention is the creator/creature pair. The book has been considered by several critics and scholars as a novel in between the gothic and science fiction and as the first one to legitimize the SF genre per se - although there are those who claim that other specific writers or literary publications inaugurated the genre.

Little more than a century later, published in 1932, Aldous Huxley's Brave New World has been considered as a science fiction work and at the same time depicts a dystopian futuristic London, where people are biologically preconditioned and psychologically conditioned to live in harmony with the laws and the social rules within a society organized by different castes. There are no religious beliefs, moral values, or the concept of family. Every doubt and insecurity is dispelled with the use of soma, a drug that guarantees instant bliss with no apparent side effects. "Christianity without tears - that's what soma is" (HUXLEY, 2007, p. 210). Children have sex education from the earliest years of life, so extravagant sexual practices never represent a moral dilemma but a healthy activity, a sort of recreation highly encouraged by the State.

More recently, published in 2003, Margaret Atwood's Oryx and Crake illustrates a (post)apocalyptic world in which an advanced elitist society is faced with an epidemic that breaks out in several countries, since a scientist comes to decimate the Earth's population through the distribution of a pill that seemed innovative but brought a lethal virus inside. The probable sole survivor wanders in search of food on a beach inhabited by genetically modified creatures. Within the theme of the end times, the author discusses the constitution of society through topics 
such as consumerism, alienation, violence, genetic engineering, bioethics, global warming, among many others. Even though the narrative presents many dystopic elements, Atwood herself does not consider it as a science fiction story; in her perspective, it stands for a speculative novel. ${ }^{2}$

Furthermore, it is possible to connect dystopic visions to the apocalyptic tradition in literature, and this is the case of Oryx and Crake. According to Mark Bosco, "contemporary dystopian fiction is a variation of apocalyptic literature, for it serves to critique actual cultural trends - political, economic, or social - observable in some form in the present situation of an author's life" (2010, p. 160). The interesting thing is that the universe in the novel is quite dystopic both before and after the disaster, so we face a sort of duplicated dystopia: the pre-catastrophe one, marked by social imbalances and extreme advances in technology, and the postcatastrophe one, featured by a wasteland where there are only remnants of a social organization that no longer exists. As Slavoj Žižek points out,

the global capitalist system is approaching an apocalyptic zero-point. Its "four riders of the apocalypse" are comprised by the ecological crisis, the consequences of the biogenetic revolution, imbalances within the system itself (problems with

2 Oryx and Crake has two sequences: The Year of the Flood, published in 2009, and MaddAddam, published in 2013. Together, the three novels became known as the MaddAddam trilogy. The Year of the Flood is neither a prequel nor a sequel to the first novel, because its plot explores the very same universe from Oryx and Crake, but from a different point of view. While the first novel focuses mainly on the elite, the second gives voice to marginalized and powerless groups. Finally, MaddAddam brings the previous novels together, gathering their characters from where the stories have ended. In this new scenario, months after the catastrophe, the pandemic survivors become a community. 
intellectual property; forthcoming struggles over raw materials, food and water), and the explosive growth of social divisions and exclusions. (2011, p. x)

All those issues appear in Oryx and Crake, being the last rider represented precisely by the shock between different discourses. Bearing this in mind, this article aims at examining the social divisions and exclusions caused by the opposition between the major role of sciences and the minor role of humanities and the arts. In this effort, Atwood's literary work is here compared with Shelley's Frankenstein and Huxley's Brave New World - particularly in what concerns the marginalization of some characters in the stories. Scientific knowledge set against the humanistic one, in this context, is the generating principle of social inequalities, and people concerned with the arts are relegated to an inferior place. In the three novels, we will see that those who value words amid the techno-scientific developments of society are condemned to live alone for not fitting in.

\section{THE CREATURE AND THE ACCESS TO LANGUAGE}

Well-known to many readers until today, Mary Shelley's Frankenstein deals with the threats of science and technology and their impressive power to awaken all kinds of fears and horrors we might hold inside. The author gave life to what would become the most famous trickster-scientist of all times, that is, "the trickster figure in literature and legend, usually a male [who] crosses boundaries, disrupts the social order, and embodies contradictions. He is a shape-changer and a liar" (STEIN, 2010, p. 143). The reader is already familiar with the old story of a being coming to life through 
the hands of Victor Frankenstein, a young student with knowledge of human anatomy, who collects parts of cadavers and spends much time secluded in a laboratory to generate a creature larger than life. Thus, the great criticism in the novel lies in the misuse of science, since it exposes the arrogance of a Promethean scientist who seeks to manipulate and control nature (STEIN, 2010).

Victor Frankenstein, however, regrets the work undertaken when he beholds the result: "I had desired it with an ardour that far exceeded moderation; but now that I had finished, the beauty of the dream vanished, and breathless horror and disgust filled my heart" (SHELLEY, 2012, p. 50). Taken by terror and aversion with this attempt to violate the natural order, he runs away. Going against the expectations of his creator, the grotesque creature, on the other hand, is far from evil at the very beginning. "What does it mean, Shelley asks as the narrative unfolds, to be human physically, emotionally, and morally? Frankenstein's creature is built of human parts. Although eight feet tall and adult in form, he is childlike, innocent, and full of good will" (STEIN, 2010, p. 144). Besides rescuing a girl who falls into a pond and helping a family near whose house he finds shelter by providing them with firewood, the creature shows interest in learning their language to establish some communication.

By degrees I made a discovery of still greater moment. I found that these people possessed a method of communicating their experience and feelings to one another by articulate sounds. I perceive that the words they spoke sometimes produced pleasure or pain, smiles or sadness, in the minds and countenances of the 
hearers. This was indeed a godlike science, and I ardently desired to become acquainted with it. (SHELLEY, 2012, p. 110-111)

The godlike science he discovers, that is, the science of language, impels him to learn the words and their sounds by observing people reading and talking to one other. Hence, ignoring the cold equations of science, from which he was conceived in Victor's laboratory, he goes toward another direction by trying to achieve language and its small parts, and certain literary classics become his most valuable secret throughout his journey.

I found on the ground a leathern portmanteau, containing several articles of dress and some books. I eagerly seized the prize, and returned with it to my hovel. Fortunately the books were written in the language, the elements of which I had acquired at the cottage; they consisted of Paradise Lost, a volume of Plutarch's Lives, and the Sorrows of Werter. The possession of theses treasures gave me extreme delight. [...] I can hardly describe to you the effect of these books. (SHELLEY, 2012, p. 127)

Resorting to literature in a world of nonstop scientific discoveries - a fact not only represented by the figure of the scientist, but also by the creature itself, a clear product of scientific equations - sounds like a paradox. This is because a peaceful coexistence between science and art is impossible in many contexts since it seems that one of them always wins the race. The shock between Victor's cold intellect and the creature's emotional side is what leads the two to destruction. "As parts of a divided self, Frankenstein is the obsessive intellect, and the creature is the feeling, emotive, vulnerable self who craves 
human connection but is also capable of violence" (STEIN, 2010, p. 144). Within the boundaries of the novel, there is no way they can be anything else but opponents.

At the end, the being of threatening appearance, contradictorily kind-hearted and vulnerable, becomes vile and deceitful when he realizes that he does not belong anywhere, and that people deny and fear his existence as he is different from everyone else. Moreover, he is subject to neglect, as Stein puts it: "as a result of Frankenstein's neglect as a father, the creature suffers from cold and hunger" (STEIN, 2010, p. 145). Thereby, following Victor's death, the creature decides to commit suicide, putting an end to the scientific extrapolations and all the misery, suffering, hatred, and contempt that had led them both to an everlasting struggle.

Farewell! I leave you, and in you the last of humankind whom these eyes will ever behold. Farewell, Frankenstein! [...] I shall die, and what I now feel be no longer felt. Soon these burning miseries will be extinct. I shall ascend my funeral pile triumphantly, and exult in the agony of the torturing flames. The light of that conflagration will fade away; my ashes will be swept into the sea by the winds. My spirit will sleep in peace; or if it thinks, it will not surely think thus. Farewell! (SHELLEY, 2012, p. 230)

Thinking of a different closure, Stein speculates, "would the creature have remained peaceful and gentle if Frankenstein had protected him and others had treated him well? Is morality a function of nature or nurture? Is it innate or learned?" (2010, p. 145). These are some of the questions that might come up to the reader after finishing Mary Shelley's gothic novel. Since the figure of the mad scientist continues to proliferate in literature, we still 
must reflect upon his role and responsibility in tales like this one an issue that will also apply to Crake, the deranged scientist behind Margaret Atwood's speculative fiction.

\section{THE SAVAGE AND THE ACCESS TO LITERATURE}

One may acknowledge that the novelists who designed the most prominent literary dystopias are Aldous Huxley, with Brave New World (1932), and George Orwell, with Nineteen Eighty-Four (1949). Yet, there is an extensive list of remarkable titles along with them, such as, for example: Yevgeny Zamyatin's We (1924), Ray Bradbury's Fahrenheit 451 (1953), William Golding's Lord of the Flies (1954), Anthony Burgess's A Clockwork Orange (1962), Pierre Boulle's Planet of the Apes (1963), Philip K. Dick's Do Androids Dream of Electric Sheep? (1968), Margaret Atwood's The Handmaid's Tale (1985), and Suzanne Collins's The Hunger Games trilogy (20082010), just to name a few. Huxley, on the one hand, builds up Brave New World through a totalitarianism "that relies on highly effective methods of persuasion that, by their scientific nature, exclude the need of physical violence". The totalitarianism of Orwell in Nineteen Eighty-Four, on the other hand, "is the quintessence of violent regimes generally associated with the images of Hitler and Stalin" (CARVALHO, 2011, p. 22, my translation).

In this context, the idea of dystopia "encompasses a series of implications, such as mass hysteria around tutelary figures, distorted views of history, the mistaken dirigisme of values, scientific exaggerations, the harms of overpopulation" (DIAS apud CARVALHO, 2011, p. 10, my translation), and so forth. Usually, if utopia works with the idealization of places and seeks optimistic 
answers, dystopia works differently: it accepts the world we live in, taking its negative traits to extremes, or it forces a return to circumstances or values long lost. Classic dystopian narratives, therefore, explore an oppressive authority over a corrupted society, in which technology is used as a tool to control the masses. There is a gloomy atmosphere emanating from the plot, in which the command of the human by technological or State machinery is predominant. There is always something about to collapse.

Utopias and dystopias from Plato's Republic on have had to cover the same basic ground that real societies do. All must answer the same questions: Where do people live, what do they eat, what do they wear, what do they do about sex and childrearing? Who has the power, who does the work, how do citizens relate to nature, and how does the economy function? (ATWOOD, 2007, p. 11)

Atwood (2007) also points out that World War I marked the end of the romantic-idealistic utopian dream in literature, as well as several real-life utopian plans were about to be consolidated bearing devastating effects. We must remember that both Communism in Russia and Nazism in Germany began as utopias. Thus, there has been a higher tendency toward literary dystopias ever since. Moreover, the author associates the severe future of Nineteen Eighty-Four with the historical context of the Cold War, whereas the more flexible future of Brave New World would have to do with the fall of the Berlin Wall.

Which template would win, we wondered? During the Cold War, Nineteenth Eighty-Four seemed to have the edge. But when the Berlin Wall fell in 1989, pundits proclaimed the end of history, shopping 
reigned triumphant, and there was [sic] already lots of quasi-soma percolating through society. True, promiscuity had taken a hit from AIDS, but on balance we seemed to be in for a trivial, giggly, drug-enhanced Spend-O-Rama: Brave New World was winning the race. (ATWOOD, 2007, p. 8)

However, utopias and dystopias can be merged in many situations; they are two sides of the same coin, and it is up to the readers to set up a distinction, depending on their perspectives and life experiences. As Atwood believes, "Brave New World is either a perfect-world utopia or its nasty, opposite, a dystopia, depending on your point of view: its inhabitants are beautiful, secure, and free from diseases and worries, though in a way we like to think we would find unacceptable" (2007, p. 9). Everything is fine, but at the same time it seems fake and extravagant: artificial people, wild consumption, excessive multiplication of eggs in laboratories, unrestrained orgies, abusive use of contraceptives, persistent hallucinations provoked by drugs to avoid boredom, the worship of Henry Ford, and so on.

In Huxley's dystopic world, we have a clear social division into castes: the Alphas, Betas, Gammas, Deltas and Epsilons. Every group wears different color uniforms: grey, mulberry, green, khaki, and black, respectively. However, what scares the reader at first sight is where these people come from - or how they hatch, to be more specific, since they are not a result of viviparous reproduction as it happened in old times, when children were brought up by their parents rather than in Hatchery and Conditioning Centers. By way of illustration, a similar split of society into categories can be seen in Andrew Niccol's Gattaca (1997), a science fiction film 
in which society is divided into those beings who are considered valid (artificially conceived in laboratories, that is, genetically perfect) and those who are not (naturally conceived, that is, born without genetic improvement). Two nightmarish stories alike, two different media.

One egg, one embryo, one adult - normality. But a bokanovskified egg will bud, will proliferate, will divide. From eight to ninety-six buds, and every bud will grow into a perfectly formed embryo, and every embryo into a full-sized adult. Making ninety-six human beings grow where only one grew before. Progress. [...] Bokanovsky's Process is one of the major instruments of social stability! [...] Ninety-six identical twins working ninety-six identical machines! (HUXLEY, 2007, p. 5)

In order to induce the multiple infants to choose the right caste, the State suggests that some castes are better than others, making use of hypnopedia - learning process by hearing while asleep or under hypnosis, which represents "the greatest moralizing and socializing force of all time" (HUXLEY, 2007, p. 23). During the process, children repeatedly listen to specific messages until they assimilate their content, and then they start to live in accordance with the patterns settled for them.

Alpha children wear grey. They work much harder than we do, because they are so frightfully clever. I'm really awfully glad I'm Beta, because I don't work so hard. And then we are much better than the Gammas and Deltas. Gammas are stupid. They all wear green, and Delta children wear khaki. Oh no, I don't want to play with Delta children. And Epsilons are still worse. (HUXLEY, 2007, p. 23) 
What disrupts the structures of this brave and terrifying new world is the arrival of John the Savage, a man raised in a reservation outside the universe taken over by aseptic laboratories and multiple twins. He is not interested in scientific and technological advances; what really matters to him is the old world, that is, God, poetry, danger, freedom, goodness, sin. "He wants the old world back dirt, diseases, free will, fear, anguish, blood, sweat, tears, and all. He believes he has a soul..." (ATWOOD, 2007, p. 15). Like the creature in Frankenstein, he does not fit in. Moreover, even if isolated from the main community, living in a hostile environment, he has an intense relationship with literary classics, particularly with Shakespeare's. From the moment when he suddenly finds the texts, he comes to read them many times all through his life.

One day [...] he came home and found a book that he had never seen before lying on the floor in the bedroom. It was a thick book and looked very old. The binding had been eaten by mice; some of its pages were loose and crumpled. He picked it up, looked at the title-page: the book was called The Complete Works of William Shakespeare. (HUXLEY, 2007, p. 113)

Literature, represented by the Savage, is a clear example of something that belongs to the past, as well as human beings conceived through viviparous reproduction. In the same way that beliefs about/in God, the books published before A.F. 150 (150 years after Ford) were all suppressed once people do not need or want to think. It resembles the suppression of books that takes place in Ray Bradbury's Fahrenheit 451, which explores a futuristic world where all books are prohibited and literally burned out in 
order to avoid dissident ideas, and perhaps because citizens are not interested in reading anymore. As Mustapha Mond tells the Savage, "You must make your choice. Our civilization has chosen machinery and medicine and happiness. That's why I have to keep these books locked up in the safe" (HUXLEY, 2007, p. 207). Along with machinery and medicine and happiness, stability also plays an important role and cannot be jeopardized by old worldly pleasures.

“[...] our world is not the same as Othello's world. You can't make flivvers without steel - and you can't make tragedies without social instability. The world's stable now. People are happy; they get what they want, and they never want what they can't get. [...] they're so conditioned that they practically can't help behaving as they ought to behave. And if anything should go wrong, there's soma. Which you go and chuck out of the window in the name of liberty, Mr Savage. Liberty!" [...] "Expecting Deltas to know what liberty is! And now expecting them to understand Othello! My good boy!" (HUXLEY, 2007, p. 193-194)

Unfortunately, the Savage's attempts to preserve the literary classics and ensure their worth to the world do not convince anyone. Even though there are other characters who are aware of the significance of those works, they would rather not care. "[...] That's the price we have to pay for stability. You've got to choose between happiness and what people used to call high art. We've sacrificed the high art" (HUXLEY, 2007, p. 194). Then, we wonder whether such an imposed stability can really bring any joy. Art, in the broad sense of the term, not only stimulates the senses but also makes you better understand the world 
you live in. Afterwards, which State would want its citizens contemplating, reading, and thinking by themselves if there is a series of convenient maneuvers at hand to silence them all?

\section{THE NEUROTYPICAL AND THE MAINTENANCE OF NARRATIVE}

According to Margaret Atwood, some of her novels have been read as science fiction, though she tends to disagree by arguing that they are speculative fiction instead, that is, stories that deal with things that might happen in a medium or long-term future. As she distinguishes,

What I mean by "science fiction" is those books that descend from H. G. Wells's The War of the Worlds, which treats of an invasion by tentacled, blood-sucking Martians shot to Earth in metal canisters - things that could not possibly happen - whereas, for me, "speculative fiction" means plots that descend from Jules Verne's books about submarines and balloon travel and such - things that really could happen but just hadn't completely happened when the authors wrote the books. I would place my own books in this second category: no Martians. (ATWOOD, 2011, p. 6)

As Atwood puts it, the debate around literary genres is quite complicated once every writer, reader or scholar has their own way of interpreting a literary work. "Much depends on your nomenclatural allegiances, or else on your system of literary taxonomy" (ATWOOD, 2011, p. 2). What does science fiction mean nowadays, when we already have a bunch of scientific and technological improvements that seemed impossible a few decades ago? One may say that the term is perhaps losing its direction and becoming outdated, since our current abstractions 
can be accomplished faster than ever. Nevertheless, science fiction will always be some steps ahead, simply because our imagination is always ahead. Despite all the nomenclatural mess and far beyond labels, the most important thing is to admit that some readings can definitely unsettle the way we have been looking at our world, and this is the case of Oryx and Crake.

The disturbing storyline is constructed almost in accordance with the protagonist, Jimmy, a 20-something man almost alone on a beach, in terms of his perspective - as a focalizer, not a narrator -. Almost because there is the presence of the Crakers, a group of humanoids conceived by Jimmy's best friend, Crake, before a pandemic that killed everyone else. Jimmy calls himself the Abominable Snowman, since to others (or even to himself) he looks like a menacing monster, an endangered species that will disappear sooner or later. Following his reminiscences while seeking food and teaching lessons to the humanoids, we come to know about Crake, who was a scientist, and Oryx, a girl discovered by the two friends in a child porn website when they were teenagers. Through JimmySnowman's recollections, we finally come to understand what happened to humankind when one of Crake's scientific innovations goes wrong - among his inventions there are transgenic plants, animals, and humans.

Before the catastrophe, society was divided into different segments. First, there were the Compounds, where wealthy people used to live, and the pleeblands, an area destined to the impoverished. Secondly, the citizens were divided into numbers people (regarding science) and words people (regarding art). We also have the children of Crake, creatures designed to replace humanity 
in the nearby future. Power is concentrated in the hands of "a paramilitary organization called CorpSeCorps and their genetic engineers, who are working toward the ultimate goal: immortality. With Crake's most ambitious project, the Paradice Method, whole human populations could be created" (LABUDOVA, 2010, p. 136). Crake's desire would be achieved through the alteration of the ancient primate brain in order to eliminate what he calls destructive features, such as hierarchy, territoriality, family trees, marriages, weapons, clothing, the torment of sexuality, symbolisms, racism - "[...] the Paradice people simply did not register skin colour" (ATWOOD, 2003, p. 305).

Scientific and artistic discourses are strongly marked in the novel by two distinct fictional institutions: the Martha Graham Academy ${ }^{3}$, a college for humanities and the arts, destined to words people; and the Watson-Crick Institute ${ }^{4}$, a college for sciences, intended to numbers people. Martha Graham is a decadent place that had prestige in the past when companies used to invest in the arts. Now it just offers risible degrees whereas Watson-Crick keeps the most important students, those who are going to be great scientists one day. Concerning Watson-Crick, "once a student there and your future was assured. It was like going to Harvard had been, back before it got drowned" (ATWOOD, 2003, p. 173). These students assume their own eccentricity and even make fun of themselves,

Watson-Crick was known to the students there as Asperger's U. because of the high percentage

3 The college's name is a reference to Martha Graham (1894-1991), modern dancer and choreographer.

4 Reference to James Dewey Watson (1928 ) and Francis Harry Compton Crick (19162004), the two co-discoverers of the DNA structure in 1953. 
of brilliant weirdos that strolled and hopped and lurched through its corridors. Demi-autistic, genetically speaking; single-track tunnel-vision minds, a marked degree of social ineptitude. (ATWOOD, 2003, p. 193)

Crake, as the geek and genius (mad) scientist coming from Watson-Crick, plays a dominant role in the story. He is cold, cynical, calculating, and manipulates everything and everyone around him. "Crake's Compounds are characterized by material comfort, purely scientific approaches, and emotional blankness" (LABUDOVA, 2010, p. 141). Besides, "manipulators manipulate feelings of human beings as well as genes in laboratories" (LABUDOVA, 2010, p. 142). Through computer games and websites, Crake worships violent entertainment, always vibrating with topics such as the extinction of entire populations. It is no accident that he turns out to be a bioterrorist.

The BlyssPluss Pill, a drug responsible for killing almost everyone on the Earth, is another of his ambitious endeavors, which "a) would protect the user against all known sexually transmitted diseases [...]; b) would provide an unlimited supply of libido and sexual prowess, coupled with a generalized sense of energy and well-being [...]; c) would prolong youth" (ATWOOD, 2003, p. 294). The multi-function drug had yet a fourth aim - this one omitted in the ads, of course -, to work as a birth control pill. For sure, the idea was way too bold and killed countless people insofar as Crake did not comply with the clinical trial period, starting to sell the product everywhere. It is a little challenging for the reader to understand his motivations. Was he a lunatic? Was he ahead of his time? Did he plan to leave the Crakers as inheritance to repopulate the Earth and start out a brand-new age? 
Although apathetic, Jimmy seems to be a reasonable guy. He had obtained a degree in Problematics from Martha Graham and worked as an advertisement writer for pharmaceutical companies. Later, Crake hires him to work in this capacity at his own business. Being a words person means to be an outcast living in a society filled with highly logical, scientifically oriented people, such as his best friend. Jimmy is considered the neurotypical, that is, "minus the genius gene" (ATWOOD, 2003, p. 194). Moreover, even though born to a genetic engineer's family and living in the wealthy Compounds, he fails to incorporate the position the system has for him; he does not identify with science, as he is interested in old words instead. He is actually "caught between the old world of Shakespeare's words and 'the brave new world' of virtual reality" (LABUDOVA, 2010, p. 138). In times of banalized violence and pornography, it is ironically through a reality show he used to watch as a teen, At Home with Anna K., that he comes to know about the bard,

Anna K. was a self-styled installation artist with big boobs who'd wired up her apartment so that every moment of her life was sent out live to millions of voyeurs. [...] Then you might watch her tweezing her eyebrows, waxing her bikini line, washing her underwear. Sometimes she'd read scenes from old plays out loud, taking all the parts [...]. This was how Jimmy first encountered Shakespeare - through Anna K.'s rendition of Macbeth. (ATWOOD, 2003, p. 84)

It is funny to think about a time when Shakespeare's plays are performed in a reality show presented by a young girl who is probably more interested in great popularity ratings than 
in literature itself. However, once Jimmy tries to justify the importance of art to civilization, Crake seems to make fun of him,

"When any civilization is dust and aches," he said, "art is all that's left over. Images, words, music. Imaginative structures. Meaning - human meaning, that is - is defined by them. You have to admit that." "That's not quite all that's left over," said Crake. "The archeologists are just as interested in gnawed bones and old bricks and ossified shit these days. Sometimes more interested. They think human meaning is defined by those things too." (ATWOOD, 2003, p. 167)

Despite the seeming provocation, Crake is not mistaken about the archeologists' concerns. It seems that the material remains of humanity represent its true heritage while imaginative structures images, words, music, for instance - do not, for the simple reason that they hold ideas, and we cannot touch them. Bones and old bricks on the one hand and imaginative structures on the other: how to measure their importance? Also members of the imaginative structures club, books are not necessarily suppressed here, but are neglected, and their contents fade into oblivion.

Better libraries, at institutions with more money, had long ago burned their actual books and kept everything on CD-ROM, but Martha Graham was behind the times in that, as in everything. [...] Who was it who'd said that all art was completely useless? Jimmy couldn't recall, but hooray for him, whoever he was. The more obsolete a book was, the more eagerly Jimmy would add it to his inner collection. (ATWOOD, 2003, p. 195)

Howsoever, keeping in mind that many of Atwood's characters are multilayered, we should not consider Jimmy a hero. Even if we 
know that he "appreciates the books lying otherwise unread in his Academy's library, we also know that they have provided him only with the insight that their wisdom is being universally ignored. His is a culture not of reflection but of consumption" (HENGEN, 2010, p. 135). Though we might see Jimmy as a victim and even feel sorry for him, he is a co-conspirator as well insofar as he engages in Crake's machinations. He "becomes an accomplice, as he assists Crake to promote The BlyssPluss Pill which is infected with the deadly virus. [...] Paradoxically, Jimmy's slogans helped Crake to sell the lethal pill" (LABUDOVA, 2010, p. 143). Therefore, curiously enough, even though numbers people have greater influence in Atwood's fictional society, a words person is the one who induces loads of people into dying. The outcome is utterly apocalyptic,

The first bulletin came in at nine forty-five. [...] Anyway, it was in Brazil. Far enough away. [...] Then the next one hit, and the next, the next, the next, rapid-fire. Taiwan, Bangkok, Saudi Arabia, Bombay, Paris, Berlin. [...] This was more than a few isolated plague spots. This was major. [...] The symptoms were high fever, bleeding from the eyes and skin, convulsions, then breakdown of the inner organs, followed by death. The time from visible onset to final moment was amazingly short. The bug appeared to be airborne, but there might be a water factor as well. [...] The keep-calm politico speeches were already underway, the stay-in-your-house megaphone vehicles were prowling the streets. Prayer had broken out. (ATWOOD, 2003, p. 324-327)

As the last man on the Earth, still not believing that Crake could be deranged enough to the point of having planned and committed such an unspeakable abomination, Jimmy - now 
Snowman - closes himself, because at the beginning he cannot see in the Crakers a real communication opportunity, just a practical joke. The fact that he talks to them at times does not mean he is really involved in social interaction. "Yet living in the aftermath of the deadly plague, he relies on words to link him to his past" (BOSCO, 2010, p. 166) and also to his future, since someday he would have to accept the humanoids' existence because, after all, what remains in such a devastated place are a few individuals and their communication skills. Jimmy-Snowman finally becomes a narrative redeemer by protecting the stories themselves, like the ones he used to read in books, as well as the narration ability, thus reassuring people's right to carry on telling stories.

At first sight, it seems that science has won for leaving its most precious invention as legacy, the Crakers, better versions of ourselves. "Though Crake sees the Crakers as the new improved human race, he does not want them to act human, to be introduced to human objects nor to ask questions" (KARLSSON, 2011, p. 13). In addition, "Crake tried to eliminate the dissemination of human narrative, but Jimmy's act of storytelling becomes a means not only for his personal survival but a revival of a human narrative" (BOSCO, 2010, p. 170). What Crake did not anticipate, therefore, was the fact that the creatures were more human than he could expect them to be , and that, along with JimmySnowman, they would restart the ancient tradition of storytelling inside the new community, giving status to words once again.

\section{ART, SCIENCE, AND STORYTELLING}

As you may have noticed so far, the dystopian futuristic nameless place from Oryx and Crake shares many similitudes with 
the dystopian futuristic London from Brave New World. First, the social division into segments: primitive civilization (reservation and the pleeblands) and modern civilization (London and the Compounds). Secondly, the social division into categories: the Alphas, Betas, Gammas, Deltas, Epsilons, savages, numbers people, words people, the humanoids (Crakers). Thirdly, a new drug to bring people happiness: soma and the BlyssPluss Pill - just like blue pills in The Matrix (1999). Finally, the conflict between science (Central London Hatchery and Conditioning Center, the Compounds, Watson-Crick Institute) and the arts (reservation, the pleeblands and Martha Graham Academy).

Huxley's Central London Hatchery and Conditioning Center, where eggs are multiplied and children are conditioned, works similarly to Atwood's high-tech bubble dome, where the Paradice Project unfolds. In these laboratories may lie the real danger of science. Huxley acknowledges that "every discovery in pure science is potentially subversive; even science must sometimes be treated as a possible enemy. Yes, even science" (2007, p. 198). In both stories, humanities and the arts lose prominence to the materialism and pragmatism of scientific events. As a result, the whole enterprise of science goes against the humanists John the Savage and Jimmy-Snowman, two men who represent old values; none of them belongs anywhere as they find themselves trapped in between two realms. In the end, the first gets himself killed, and the second inherits a wasteland.

Even though we might place Crake alongside many scientists in literature, like Prospero, Dr. Faustus, Professor Lidenbrock, Dr. Moreau, Dr. Jekyll, Dr. Simon Bacamarte, for instance, he has been 
often compared to Victor Frankenstein, since the mad scientist archetype gained prominence most notably with Mary Shelley's work. Oryx and Crake, "written when contemporary scientific advances in bioengineering are on the brink of creating new life forms, participates in the tradition that Shelley began, reminding us again of the power and danger of science and technology" (STEIN, 2010, p. 143). Both Frankenstein and Crake(nstein) "employ the cutting-edge technologies of their time periods to create new humanoid creatures, but the technology available to Frankenstein is more limited than that available to Crake" (STEIN, 2010, p. 143). Victor is naive and inconsequent; Crake is more than that. The former does not have history to teach him the necessary lessons, whereas Crake and any scientist today have a number of previous disasters to learn from and, consequently, can come to their senses and avoid the same past mistakes.

The context in which he works differs from Frankenstein's. Shelley's scientist must work alone; his project is an anomaly. In contrast, Crake's project is an extension of the kinds of technological innovation, such as gene splicing and xenotransplantation, used by the top scientists of his society, who are well paid to conduct such research. Furthermore, his amorality and his purported focus on products for profit are commensurate with the amoral profit-driven ethos of the pharmaceutical companies that control a large segment of his society's economy. (STEIN, 2010, p. 146-147)

On the one hand, Crake is unreliable, unsentimental, has focus on marketing and obsession with destruction. Victor, on the other hand, is just a curious young man trying to test nature 
and its limits as well as his capacity to create new beings. He acts on impulse, unlike Crake, who does not act without a previous scheme. Anyhow, "the tragedies in both of these books stem from the scientist-characters' lack of balance, their neglect of emotion and their over-reliance on reason and science" (STEIN, 2010, p. 153). Nonetheless, despite so much emphasis on science, we see language and narrative returning in the figures of Frankenstein's creature and Crakenstein's humanoids.

Frankenstein's unnamed creature learns how to read by himself. He is "very large, strong, and ugly, but he has the emotions, needs and vulnerabilities of a human" (STEIN, 2010, p. 143). Crake's creatures "are beautiful, but they have been engineered to possess unusual genetic features and to lack the emotional complexities of humans" (STEIN, 2010, p. 143). However, even though engineered with such characteristics, the Crakers start to ask for origin stories and to develop symbols and rituals, something Crake would not have approved of. "They're up to something though, something Crake didn't anticipate: they're conversing with the invisible, they've developed reverence" (ATWOOD, 2003, p. 157). These events only prove that the Crakers are as able to have emotions and needs as any human being is. Therefore, they can follow Jimmy-Snowman's footsteps, learning and valuing the old things that will be vital in a devastated landscape where science does no longer take place. Jimmy-Snowman "sees himself as a kind of human lexicon, the last repository of a language that will vanish when he dies" (ATWOOD, 2003, p. 154); then, whether he likes it or not, he needs to convey all his knowledge.

Furthermore, considering that the humanoids cannot avoid myths and stories - though they have been projected with no 
creative features -, they possibly represent a last hope for the Earth to keep on existing. In addition, along with Jimmy-Snowman and the Crakers, it seems that we are back to a storytelling primitive campfire. They are a combination of John the Savage and Frankenstein's creature: all outsiders in a domain in which language and the arts have always been ignored. Nevertheless, through the three novels addressed here in comparison, a positive movement is evident: in the first place, we have simple access to language, since the creature needs to learn how to read and communicate; then, we have access to literature, through which the Savage survives for a while in his old world; finally, we have the maintenance of narrative once Jimmy-Snowman becomes its guardian.

Therefore, by combining themes explored in Shelley's Frankenstein and Huxley's Brave New World, Atwood's Oryx and Crake mixes scientific echoes of a literary tradition with futuristic possibilities that are already occurring at present. For this reason, one may say that we have a brave new pandemic world with its own Crakenstein, the trickster-scientist who heads a society split into scientific and artistic discourses - a social imbalance that contributes to announcing the entire disaster that us readers can follow throughout the novel. Ironically, after the catastrophe, when the rules of science do not apply anymore, it is a neurotypical who survives, embracing his existence all through the act of storytelling.

Even as Atwood asks readers of Oryx and Crake to speculate about the disastrous prospects that may confront humanity in the not-so-distant future, she 
also, in a gesture true to most apocalyptic fiction, offers in the closure of her novel a surprising revelation of belief in a future of humankind. (BOSCO, 2010, p. 171)

In this sense, in accordance with Atwood herself, Oryx and Crake would not be for or anti-science, it would be a neutral tool (STEIN, 2010). Perhaps the aim of the novel is not to emphasize scientific breakthroughs, but at least to make the reader consider their benefits and their possible risks while associating the story to our current way of life. Thus, the novel does not lend itself to be a simple warning against the dangers of science, but a satirical portrait of a controversial social design that has many things to do with our own. It is important to consider that the real threat is not science itself, but the way people relate to it. Hence, as readers, we must recognize that - both inside the novel and outside its pages the places of art and science are not that clearly detached.

\section{FINAL CONSIDERATIONS}

Even with a less tragic closure by bringing Jimmy-Snowman as a survivor whereas the creature and the Savage resort to suicide - Oryx and Crake presents a possible rereading of Shelley's and Huxley's novels, leading the words person to a better denouement, yet still in a catastrophic scenario. Atwood's novel celebrates and updates the classics in some way, transposing them to a brand-new universe. We have, as a result, literary texts from the past shedding lights on contemporary fiction and the other way around. As a literary intertext, it seems that the novel really has a long list of fellows; Frankenstein and Brave New World are only the tip of the iceberg, so to speak. As stated by Botting, "inured to Gothic shocks 
and terrors, contemporary culture recycles its images in the hope of finding a charge intense enough to stave off the black hole within and without, the one opened up by postmodernist fragmentation and plurality" (2002, p. 298). This is precisely what some types of fiction do, as they commit to transform the profound anxieties of contemporary individuals into remarkable literary manifestations.

Accordingly, Atwood's work is representative of a great intersection, with Oryx and Crake enabling an interesting arrangement of elements from gothic, science fiction, speculative fiction, utopia, dystopia, and apocalyptic fiction. With respect to dystopias, by relating to political issues, they are a projection of real life; they amplify real life into fictional constructions that may be perceived as a criticism against something that occurs in the empirical world. For this reason, dystopias are commonly associated with specific historical contexts, emerging in accordance with different phases throughout history. Historical events such as World War II, the Cold War, September 11 attack, and the War on Terror have been bringing up in literature subjects like totalitarian regimes, fear of the State, anxieties about the body, identity policies etc. In a world of real dystopias, the picture has been always shifting, and the greatest tragedies of history provide fictional dystopias with several inspiring elements. Nowadays, we might turn to other subjects as well, such as environmental crises, biogenetics, digital surveillance, social inequalities, famine, diseases, political disputes, and so on - issues that already dominate or are on the verge of dominating our daily life.

For years now we have been amusing ourselves by watching and reading about apocalypses in films and literature, and for a 
long time now we have been witnessing scientists warning people about the hazards of certain practices and the likelihood of a new deadly virus that would eventually spread and bring chaos. The new coronavirus (SARS-CoV-2) was knocking on the door, and we refused to listen. If pandemics already happened in the past, why wouldn't they happen again? Evidently, now we were faced with different biosecurity procedures, such as isolation, quarantine or lockdown, the use of alcohol gel, disposable materials, masks and face shields etc. However, existential questions and political and ideological disputes are believed to have always been present. In addition, we may wonder whether the covid-19 scenario will install a new apocalyptic dystopian chapter in literature and other media - or is it more of the same?

Howsoever, it is impossible not to draw a parallel between the pandemic we have been through in real life and the pandemic we encounter in Margaret Atwood's Oryx and Crake. While Crake is indeed a bioterrorist who designs the lethal virus in his labs, in 2020 some people honestly believed in a conspiracy theory in which Chinese scientists would have created the new coronavirus on purpose. Prejudice and xenophobia may also be seen regarding the dispute as to which nation could find an effective vaccine first. Besides, following Crake's bad faith while selling the BlyssPluss Pill to serve as a magical multi-function drug, now we could see some world leaders also taking advantage of people's naivety and despair by endorsing the use of medication with no scientific evidence or not recommended by the World Health Organization (WHO).

Due to ignorance, political and religious manipulations, a scenario of denial and disdain for scientific facts was established 
in many countries. Curiously, the antagonizing forces we were describing before, science versus art, do not apply at this point because, in our present apocalyptic vision, they were cast for the same team. On the one hand, people at the front line in hospitals, working to save lives and make the calamity less painful, as well as people in labs, running out of time to try to find efficient treatments and a viable vaccine; on the other hand, artists from all fronts, helping to turn our lives in isolation into something less miserable through books, films, streaming, TV programs, music, videogames, and so forth. As an apparently civilized society, we need science, we need culture, we need nature, among other things. Therefore, it would be more helpful for all of us to watch science and art getting along as good friends rather than fighting as rivals on a battlefield.

However then, where do we stand in this landscape? Are we more like Crake? Are we more like Jimmy-Snowman? Or more like the Crakers? What can we really preserve and what lessons can we learn from this hideous situation? As Waltonen points out, for tales "of apocalypse to be told, someone must survive [...] - long enough to be described or to narrate the end for an imagined future audience. This need for a narrator - for at least the hope of survival - has been with us since Mary Shelley's The Last Man" (2015, p. xii). Just like some literary characters and narrators, we truly suffer from a compulsion to narrativize; we survive day after day through stories, whatever they are. Stories to remember, to create, to teach, to inform, to deconstruct. "Across the man-made, man-helped, and man-indifferent apocalypses", we "must not simply observe. We must bear witness. We must act" (WALTONEN, 2015, p. xvii). Other epidemics and pandemics are likely to come, 
and, as ordinary numbers and words people, we may not be able to prevent millions from dying, but one act of survival is trying to keep our storytelling practices ongoing.

\section{REFERENCES}

ATWOOD, Margaret. Oryx and Crake. New York: Anchor Books, 2003.

ATWOOD, Margaret. Introduction by Margaret Atwood. In: HUXLEY, Aldous. Brave New World. London: Vintage Books, p. vii-xvi, 2007.

ATWOOD, Margaret. In Other Worlds: SF and the Human Imagination. New York: Random House, 2011.

BARRICELLI, Jean-Pierre; GIBALDI, Joseph (Ed.). Glossary. In: BARRICELLI, JeanPierre; GIBALDI, Joseph (Eds.). Interrelations of Literature. New York: The Modern Language Association of America, p. 307-316, 1982.

BOSCO, Mark, S. J. The Apocalyptic Imagination in Oryx and Crake. In: BOUSON, J. Brooks (Ed.). Margaret Atwood: The Robber Bride, The Blind Assassin, Oryx and Crake. London/New York: Continuum International Publishing Group, p. 156-171, 2010.

BOTTING, Fred. Aftergothic: Consumption, Machines, and Black Holes. In: HOGLE, Jerrold E. (Ed.). The Cambridge Companion to Gothic Fiction. Cambridge: Cambridge University Press, p. 277-300, 2002.

BRADBURY, Ray. Fahrenheit 451. New York: Ballantine Books, 1996.

CARVALHO, Alfredo Leme Coelho de. A Ficção Distópica de Huxley e Orwell. 2. ed. UNESP - Campus de São José do Rio Preto: Laboratório Editorial IBILCE, 2011. HENGEN, Shannon. Moral/Environmental Debt in Payback and Oryx and Crake. In: BOUSON, J. Brooks (Ed.). Margaret Atwood: The Robber Bride, The Blind Assassin, Oryx and Crake. London/New York: Continuum International Publishing Group, p. 129-140, 2010.

HUXLEY, Aldous. Brave New World. London: Vintage Books, 2007.

KARLSSON, Paola. How Human Are the Crakers? A Study About Human Identity in Margaret Atwood's Oryx and Crake. Linnaeus University, Sweden, 2011. Available at: https://www.diva-portal.org/smash/get/diva2:430888/ FULLTEXT01.pdf. Access on 31 oct. 2020. 
LABUDOVA, Katarina. Power, Pain, and Manipulation in Margaret Atwood's Oryx and Crake and The Year of the Flood. Brno Studies in English, v. 36, n. 1, 2010. Available at: https://digilib.phil.muni.cz/handle/11222.digilib/105100. Access on 31 oct. 2020.

SHELLEY, Mary. The Last Man. New York: Dover, 2010.

SHELLEY, Mary. Frankenstein. London: Penguin English Library, 2012.

SLUSSER, George; GUFFEY, George. Literature and Science. In: BARRICELLI, Jean-Pierre; GIBALDI, Joseph (Eds.). Interrelations of Literature. New York: The Modern Language Association of America, p. 176-204, 1982.

STEIN, Karen F. Problematic Paradice in Oryx and Crake. In: BOUSON, J. Brooks (Ed.). Margaret Atwood: The Robber Bride, The Blind Assassin, Oryx and Crake. London/New York: Continuum International Publishing Group, p. 141-155, 2010. WALTONEN, Karma. "[It] Was Zero Hour, You Said Be Brave": Tracing Atwood's Apocalypses. In: WALTONEN, Karma (Ed.). Margaret Atwood's Apocalypses. Newcastle upon Tyne: Cambridge Scholars Publishing, p. ix-xix, 2015. ŽIŽEK, Slavoj. Living in the End Times. London/New York: Verso, 2011. 